\title{
SERO-PREVALENCE AND ASSOCIATED RISK FACTORS OF MAEDI-VISNA VIRUS IN SHEEP POPULATION OF SELECTED AREA OF EASTERN AMHARA, ETHIOPIA
}

\author{
L. YIZENGAW ${ }^{1 *}$, N. BELAYNEH ${ }^{1}$, A. ZEGEYE ${ }^{1}$, F. AKLILU $^{2}$ AND A. KEFALE ${ }^{1}$
}

${ }^{1}$ Sirinka Agricultural Research Centre, Po. Box: 74, Sirinka, Ethiopia

${ }^{2}$ National Animal Health Diagnostic and Investigation Centre, Po. Box: 04, Sebeta, Ethiopia

\begin{abstract}
Maedi-visna virus (MVV) causes a significant economic loss through morbidity, mortality and carcass weight loss in sheep worldwide. This cross-sectional study was conducted to determine the prevalence and identify associations with potential risk factors of MVV virus infection in the selected area of the eastern Amhara region, Ethiopia. A total of 494 sheep blood sera were collected during the period from November, 2017 to October, 2018 and examined using Indirect enzyme linked immuno-sorbent assay (I-ELISA) to screen specific antibodies against MVV. From the total tested sample 3.24\% (16/494) were positive for the presence of antibodies against MVV in the area. The sero-prevalence of MVV was not significantly different between associated risk factors of breed, sex, age, production system, flock size and body condition score (P> 0.05). Awassi cross sheep distributor farm and ranch were incriminated as a source for Maedi-visna virus infection and effective control measures should be implemented through appropriate way of testing and culling mechanisms of all seroreactor ewes and their progeny. High sensitive screening test should be practiced and implemented during introduction of new flocks from abroad and before distribution of Awassi cross breed rams from ranches and multiplication center to smallholder farms and individual farmers. In addition further epidemiological study (research) should be done in sheep producing areas of the country to know the level of infection at national and country level.
\end{abstract}

Key words: Eastern Amhara, Maedi-visna virus, Risk factors, Seroprevalence, Sheep

\section{INTRODUCTION}

Sheep production plays a great economic role in the small holder farmers of Ethiopian. Sheep population in Ethiopia is estimated about 31.30 million, out of which, $99.81 \%$ is indigenous breeds (CSA, 2017/18). More than $75 \%$ of the population is located in the highlands and less than $25 \%$ in the lowlands. The sheep population in the Amhara regional state is about 11, 086,083. This contributes $35.4 \%$ to the total population of the country (CSA, 2017/18).
Sheep are main sources of income and provide food proteins in most parts of Ethiopia of rural society. Their growing rate relatively fast and good proficiency rates and have a capacity to give mostly twins and triple births with short lambing period as compared to cattle. In Ethiopia they contribute a significant value of the national meat and skins production (Tibbo, 2006). However, relatively due to low productive potential of the local indigenous breeds, the

\footnotetext{
*Corresponding Author
} 
Ethiopian government had been introducing high potential sheep breeds of Hampshire, Morrisdale, Awassi and Dorper from UK, SA and Israel since the early 1970's to upgrade the genetic makeup of the local sheep breeds (Gizaw et al., 2013; Getachew et al., 2016).

Imported sheep were stocked and crossed with the local Menz and Horro breed sheep in Debre Birhan and Amed Guya sheep breeding and multiplication centers and cross-rams were selected for distribution. The distribution was primarily for sheep farms established by peasant associations in different parts of the country with the intention that associations could distribute to other local breeders easily. Among the established association Agarfa which was used as the former farmers training center in the country and Arsi Rural Development Unit (ARDU), which owned the rams of Corriedale and Awassi in 1981 was used as the center for cross breed ram multiplication and distribution to other individual breeder farmer (Gizaw et al., 2013; Getachew et al., 2016).

Despite the genetic improvement, an occurence of a new case with undefined etiology characterized by a respiratory embarrassment appeared in Agarfa and Arsi Rural Development Unit (ARDU) sheep farms in 1990 (BoA, 2000; Tibbo et al., 2001). The disease caused $10 \%$ mortality affecting mainly adults and had no response to antibiotic treatments. Finally, sera samples were sent to Pirbright laboratory (UK) and specific antibody for the Maedi-visna virus (Ovine Progressive Pneumonia-OPP) was detected in $90.7 \%$ (39/43) tested samples. Therefore; the occurrence of MVV in Ethiopia was first detected in imported breed in 1986 at Agarfa sheep ranch Bale province, Ethiopia (Ayelet et al., 2001).

MVV/OPP is a slowly progressive disease of sheep and rarely goats reported first in the Iceland in 1939 and subsequently eradicated, has been reported in major sheep rearing countries throughout the world except Australia and New Zealand. (Jones and Hunt, 1983; Vorster et al., 1996; Murphy et al., 1999; Radostits et al., 2000; Kahn et al., 2005). MVV is a chronic disease of adult sheep characterized by progressive interstitial pneumonia and other syndromes such as meningo-encephalitis, indurative mastitis and arthritis (Lujan et al., 1994). It is caused by a non-oncogenic retrovirus agent, which is belongs to the subfamily Lentivirinae. Transmission occurs more readily between dams and lambs via colostrum and milk, and among confined individuals probably via respiratory secretions (Preziuso et al., 2009).

In Ethiopia the detection of the virus, since 1986-1989, it has been assumed that MVV is an emerged disease introduced to the country through the imported sheep breeds. Previous study reports from the assessment of the disease in and around the stocking and rearing centers of North Shewa showed that the disease became one of the most important diseases of respiratory system of sheep in the central Ethiopia. The infection is persistent, so antibody detection is a valuable tool for identifying virus carriers (Ayelet et al., 2001; Tibbo et al., 2001; Woldemeskel et al., 2002).

In the country, outbreaks of unidentified diseases often occur and a considerable number of sheep die with signs of respiratory embarrassment. When MVV is introduced into a new area, the mortality rate may reach 20 $30 \%$. The mortality rate is low in regions where MVV is endemic; annual losses rarely exceed $5 \%$ in a flock, even when nearly $100 \%$ of the flock is infected (Peterhans et al., 2004). Still there is a paucity of information regarding the presence and significance of MVV in Ethiopia. Although few research work, particular farms and breeding centers have been reporting MVV cases in eastern Amhara, Ethiopia, the extent 
to which the disease disseminated has not been established yet and there was no information regarding to this type of disease in farmer level as well.

Therefore this study was designed to estimate the sero-prevalence status of the MVV infection and to determine the potential associated risk factor in the study areas.

\section{MATERIALS AND METHODS}

Study area: Two administrative zones (South Wollo and North Wollo) were selected purposively based on the history of Awassi cross sheep population numbers. From each zone representative districts were again selected purposively based on their location, proximity and accessibility to road. Usually Awassi cross sheep were distributed around the highland areas of eastern Amhara and study districts were selected based on Awassi cross sheep distribution which practiced the crop - livestock mixed production system.

Legambo district is situated about $500 \mathrm{Km}$ North of Addis Ababa at a Latitude, $11^{\circ} 00^{\prime}$ $0.00^{\prime \prime} \mathrm{N}$ and Longitude, $39^{\circ} 00^{\prime} 0.00^{\prime \prime} \mathrm{E}$ and an elevation of range from 1500 to 3700 meter above sea level. The sheep populations of the area were 120,993 . The annual rain fall of the area ranges from 950-1200 $\mathrm{mm}$. The mean annual minimum and maximum temperatures are $1.5^{\circ} \mathrm{C}$ and $23.3^{\circ} \mathrm{C}$, respectively and the area experiences a bimodal rain fall patterns with a short rainy season which occurs from January to March and long rainy season which starts at the end of June and ends at early November (Tefera and Mulate, 2016).

Gazobelay district (Wadila former) is found about $600 \mathrm{Km}$ of Addis Ababa at a latitude, $11^{\circ} 50^{\prime} \mathrm{N}$ and longitude, $38^{\circ} 50^{\prime} \mathrm{E}$ and an elevation of ranges from 700 to 3200 meters above sea level. The sheep populations of the area were 143,133 . The rainfall pattern is bimodal, with two-rainfall season, belg (February/March - April) and meher (July October/November) and the mean annual rainfall amount is on average about $950 \mathrm{~mm}$. This area has three seasons of sub-humid agroclimatic zone with mean daily temperature ranges from $16-21^{\circ} \mathrm{C}$. Months of June to August are main rainy seasons; months of September to February are dry seasons, while months of March to May are short rainy season (Zegeye et al., 2014).

Study animals and their management: The animals used for this study were local indigenous and Awassi cross bred sheep. Sheep above six months of age were sampled. In this study the production system was classified into two based on management systems of sheep owners in the study areas. In extensive system, sheep were spent all the day on grazing pasture on fallow lands and crop residues usually with no extra-supplement and sheltered during the night. This management system was basically practiced in small holder sheep producers. In semi-intensive production system owners were supplemented extra feed sources in addition to grazing. This production system was practiced by the sheep multiplication stations.

Study design and sampling strategy: Crosssectional sero-epidemiological study was conducted from November, 2017- October, 2018. Multistage stratified cluster sampling methods were used in Legambo and Gazobelay districts and respective three peasant associations from each district were selected purposively based on accessibility and the history of Awassi cross ram distribution and high population of sheep. Finally, study units were sampled using simple random sampling method and a representative sampled animal were selected.

Sample size determination: Since this study was the first in these area, the total sample size 
were determined using the formula for simple random sampling technique (Thrusfield, 2007) with 5\% desired absolute precision level, 50\% expected prevalence and a $95 \%$ confidence interval. Accordingly, 384 sheep samples were selected. But to increase the precision and accuracy, the sample size were maximized to 521. The number of animals sampled from each districts was proportionally distributed based on sheep population in the study districts. From a total sampled animal 27 serums were discarded due to different factors (hemolysis, less amount). Over all 494 serum samples were tested, analyzed and interpreted.

Blood sample collection: Blood samples were taken from the jugular vein of sampled sheep. Sterile vacutainer tubes and needles were used for each animal and about $5 \mathrm{~mL}$ blood sample was taken. Each sample from each animal was labeled by using codes describing the specific animal. The tubes were kept overnight at a room temperature to allow clotting. Next morning the clotted bloods in the tubes were centrifuged at $3000 \mathrm{rpm}$ to obtain clear serum. Then serum were separated into $1.8 \mathrm{~mL}$ cryo-vial and were preserved at $-20^{\circ} \mathrm{C}$ in Kombolcha Regional Animal Health Diagnostic Laboratory and Sirinka Agricultural Research Center until they were processed and analyzed in National Animal Health Diagnostic and Investigations Center, Sebeta, Ethiopia (Tefera and Mulate, 2016).

Serological examination and analysis: The sera samples were tested for the presence of specific antibody against Maedi-visna virus using Indirect enzyme-linked immune sorbent assay test (I-ELISA), MVV/CAEV serum verification version VISNAS ver 1217 EN (IDvet, 310, Rue Louis Pasteur - GrabelsFrance). The test was performed according to the manufacturer's manual. The results of the test were considered valid only if optical density of a positive control serum $\left(\mathrm{OD}_{\mathrm{PC}}\right)$ was higher than 0.350 and $\mathrm{OD}_{\mathrm{PC}}$ was more than three times higher than optical density of a negative control serum $\left(\mathrm{OD}_{\mathrm{NC}}\right)$. The optical density of a serum sample (ODsample) was recalculated into percentage of $\mathrm{OD}_{\mathrm{PC}}(\mathrm{S} / \mathrm{P} \%)$ adjusted by $\mathrm{OD}_{\mathrm{NC}}$ with the formula: $\mathrm{S} / \mathrm{P} \%=\left(\right.$ ODsample $\left.-\mathrm{OD}_{\mathrm{NC}}\right) /$ $\left(\mathrm{OD}_{\mathrm{PC}}-\mathrm{OD}_{\mathrm{NC}}\right) \times 100 \%$. The interpretations was samples presenting as $\mathrm{S} / \mathrm{P} \%$, equal or below $50 \%$ are considered as negative, between $50 \%$ and $60 \%$ are considered as doubtful and equal or above $60 \%$ are considered as positive. The manufacturer cut-off of $50 \%$ sensitivity and specificity were $91.7 \%$ and $98.9 \%$ respectively (Nowicka et al., 2014).

Data management and analysis: All data collected for this study were entered in Ms-Excel spread sheet, arranged and analyzed using STATA version 14.0 software. Descriptive statistics were used to estimate the seroprevalence of Maedi-visna virus antibodies in the area. Risk factors such as breed, age, sex, body condition score, flock size and production system, were considered and their difference with sero-positivity was tested by chi square $\left(\chi^{2}\right)$. The relationship of associated risk factors with positive serological test result was analyzed by logistic regression. When the $\mathrm{P}$ value less than 0.05 , it was considered as statistically significant.

\section{RESULTS}

In this study a total of 494 sheep serum samples, 149 from local and 345 from Awassi cross breed were collected from two district of North Wollo (Gazobelay) and South Wollo (Legambo) zones to identify specific antibodies of maedi visna using I-ELISA serological test. From a total sample tested $3.24 \%$ (16/494) were positive for the identification of antibodies against Maedi visna virus (MVV) in the area. There was no significance difference $(\mathrm{P}>0.05)$ in seroprevalence among both districts and all peasant associations; however there was slight numerical difference across each district and peasant associations in presence MVV 
infection. The differences between MVV seroprevalence in sheep per districts and peasant associations as well as their associations are summarized (Table 1).

The logistic regression odd ratio analysis of attribute risk factors indicated no significance difference $(\mathrm{P}>0.05)$ in sero-positivity between sheep of different breed, sex, age, body condition score, and production system and flock size. During the statistical analyses of all risk factors, the first level of each independent variable was used as a reference category (Table 2).

Table 1. Mean sero-prevalence of Maedi-visna virus in sheep and their associations with risk factors

\begin{tabular}{llcccc}
\hline Variables & & $\begin{array}{c}\text { No. of } \\
\text { sample }\end{array}$ & $\begin{array}{c}\text { No. of } \\
\text { positive }\end{array}$ & $\begin{array}{c}\text { \% } \\
\text { (Prevalence) }\end{array}$ & $\begin{array}{c}\chi^{2} \\
\text { (P- value) }\end{array}$ \\
\hline Districts & S. Wollo (Legambo) & 221 & 4 & 1.8 & $2.61(0.14)$ \\
& N. Wollo (Gazobelay) & 273 & 12 & 4.4 & \\
\hline Peasant & Gimba (023) & 116 & 3 & 2.6 & $4.33(0.50)$ \\
association & Chiro (025) & 42 & 1 & 2.4 & \\
& Dembesh (026) & 63 & - & - & \\
& Tachtalet (011) & 101 & 4 & 4 & \\
& Lay talet (012) & 133 & 7 & 5.3 & \\
& Shriya genet (07) & 39 & 1 & 2.6 & \\
\hline Total & & 494 & 16 & 3.24 & \\
\hline
\end{tabular}

Table 2. Logistic regression analyses (LR) of risk factors with dependent Maedi-visna virus sero-positivity in sheep of study area

\begin{tabular}{llcccccc}
\hline & Risk factors & $\begin{array}{c}\text { No. of } \\
\text { sample }\end{array}$ & $\begin{array}{c}\text { No. of } \\
\text { positive }\end{array}$ & $\begin{array}{c}\text { Prevalence } \\
(\%)\end{array}$ & P-value & OR & CI 95\% \\
\hline Breed & Local(Indigenous) & 149 & 4 & 2.7 & 0.65 & - & \\
& Awassi cross & 345 & 12 & 3.5 & & 1.61 & $0.37-6.87$ \\
\hline Sex & Female* & 306 & 12 & 4 & & - & \\
& Male & 188 & 4 & 2.12 & 0.27 & 0.64 & $0.17-2.41$ \\
\hline Age & $<2$ years (young)* & 238 & 7 & 3 & 0.91 & - & - \\
& 2-4 years (adult) & 179 & 6 & 3.5 & & 0.87 & $0.26-2.95$ \\
& $>$ 4 years (old) & 77 & 3 & 3.9 & & 0.82 & $0.18-3.78$ \\
\hline Body & Poor* & 104 & 6 & 5.8 & 0.25 & - & \\
condition & Moderate & 290 & 7 & 2.4 & & 0.48 & $0.15-1.55$ \\
score & Good & 100 & 3 & 3 & & 0.80 & $0.17-3.86$ \\
\hline Production & Extensive & 468 & 16 & 3.24 & - & & \\
system & Semi- intensive & 26 & & & & & \\
\hline Flock size & $<13$ (small)* & 140 & 5 & 3.6 & 0.14 & & \\
& $13-28$ (medium) & 229 & 4 & 1.7 & & 0.26 & $0.06-1.08$ \\
& $>28$ (large) & 125 & 7 & 5.6 & & 0.93 & $0.19-4.60$ \\
\hline Total & & 494 & 16 & 3.24 & 0.79 & & \\
\hline
\end{tabular}

* Reference category 


\section{DISCUSSIONS}

Maedi visna causes a significant economic loss through morbidity, mortality and carcass weight loss in sheep worldwide. Seroprevalence of Maedi visna virus (MVV) has been established at different times from various countries including Ethiopia. The result of the present study conducted in two districts and six peasant associations of eastern Amhara region, Ethiopia showed an overall sero-prevalence of $3.24 \%$ MVV infection in sheep. This sero-prevalence found in our study area indicating the occurrence and wide distribution of MVV infection in sheep production systems in selected area of eastern Amhara region, Ethiopia.

The $3.24 \%$ prevalence of MVV in this study was in line with the reports of Mahin et al. (1984) $2.7 \%$ in Moroco, $2.41 \%$ in Manitoba, Canada, Sihvonen et al. (2000) $1.6 \%$ in Finland, Aslantas et al. (2002) 1-5-2.6\% in Hatay region, turkey, Getnet et al. (2010) 6\% in north Omo, Ethiopia, Shuaib et al. (2010) and Tefera and Mulate (2016) 3.2\% in Eastern Amhara, Ethiopia. However, the seroprevalence result of the present study is much lower than many of the previous reports in Ethiopia, viz. $74 \%$ in central Ethiopia (Woldemeskel et al., 2002), 62.5\% in central cool highland (Garedew et al., 2010), 88\% and $20 \%$ in Debre-Brhan sheep breeding center and Arsi, respectively (Getnet et al., 2010), 70.4\% in Sheno agricultural research center (Seyoum et al., 2011) and $15.6 \%$ in eastern Amhara region (Tsegaw and Ademe, 2012).

The findings in this study were also much lower than in other countries of the world. For instance, a prevalence of $19 \%$ in Canada (Simard and Morley, 1991), 15.6\% in culled ewes in Alberta, Canada (Fournier et al., 2006), $50 \%$ in Palestine (Hananeh and Barhoom, 2009), 28.8\% in Germany (Hüttner et al., 2010), $15.3 \%$ was reported in Turkish sheep (Preziuso et al., 2010), 19.4\% in Kirikkale district, Turkey (Azkur et al., 2011), 18\% in Wyoming sheep, USA (Gerstner et al., 2015) and $29.6 \%$ in Khorasan-e Razawi province, Iran (Norouzi et al., 2015). Such inconsistency (variation) in the prevalence rates of MVV might be the variation in the diagnostic tests, sampling method used, the prevalence variability within the population studied, the characteristics of the animals forming the population, susceptibility of different breeds to the disease, management practices and measures taken to control the disease.

This study showed a variation in seroprevalence of MVV between different study districts $(1.8 \%$ to $4.4 \%)$. Similar results were obtained in different parts of Quebec (14.5\% to $69 \%$ ) (Shuaib et al., 2010), in turkey (3.8\% to $41.2 \%$ ) (Alkan and Tan, 1998), in Iran (6.7\% to72.2\%) (Norouzi et al., 2015) and indifferent parts of Ethiopia ( $0.6 \%$ to $88 \%$ ) (Getnet et. al., 2010). The spatial difference in distribution of positive cases might be explained by the introduction of carrier animals from an infected area to disease free zones, the management practices and the bio-security implemented by farm owners. The sero-prevalence finding in Legambo (1.8\%) and Gazobelay (4.4\%) districts was quiet interesting. These zones are geographically located far from severely affected sheep ranches and it is suggested that the disease might have been spread along with the distribution of Awassi crossbred rams.

There was no significant difference in seroprevalence between male and female sheep ( $\mathrm{P}>0.05)$, which was in agreement with findings of Woldemeskel et al. (2002), Seyoum et al. (2011) and Tefera and Mulate (2016). The breed related sero-prevalence of MVV infection in present study showed no statistical significant difference between breeds $(\mathrm{P}>0.05)$ which was in line with Tefera and Mulate (2016). The possible explanation for this similarity could be 
the fact that animals rearing condition in the study areas was similar (extensive) and different breeds were herded together without separation and sheep of different breeds were in direct contact with each other. In contrast to our finding, susceptibility difference was reported between Menz and Awassi sheep breeds (Seyoum et al., 2011; Tsegaw and Ademe, 2012). This breed susceptibility difference could be related to the influence of traits of particular family lines, the strain of the virus and the result of one or more recessive genes (Simard and Morley, 1991).

In this study result indicated that no significant variation in sero-prevalence among age groups ( $\mathrm{P}>0.05)$, among body condition score $(\mathrm{P}>0.05)$, between production system ( $\mathrm{P}>0.05)$, among flock size $(\mathrm{P}>0.05)$. However, there was a little numerical deviation. These findings were disagreed with the report of Ayelet et al. (2001), Getnet et al. (2010), Tsegaw and Ademe (2012) and Tefera and Mulate (2016) which were reported that the sero-prevalence had significantly differed in the mentioned risk factors. This was due to the management system, sample size and the proportion of sampled animal across each risk factor difference.

Even though, the finding of the present study prevalence was low it revealed that MVV is widely distributed in eastern Amhara region, Ethiopian high sheep population areas. However, there was no statistically significance difference across breed; the frequency was higher in Awassi cross sheep as compared to the indigenous local breeds and the economic

\section{REFERENCES}

Alkan F and Tan M, 1998. Comparative study on the diagnosis of maedi-visna infection in serum and colostrums samples using agar gel immune diffusion (AGID) technique. Dtsch Tierarztl Wochenschr, 105(7): 276-278 losses could be huge due to low production and productivity from MVV influence in cross breed. Hence, the finding of MVV infection does not only suggest the occurrence of the disease in sheep population of the study area, but also give attention for the presence of foci of infection that might serve as source of infection for the distribution of the disease into free animals around and elsewhere in the sheep producing areas for upgrading purpose of local sheep and also through marketing practice. Awassi cross sheep distributor farm and ranch were main challenged site as a source for maedi visna virus infection and effective control and prevention measures to be implemented through appropriate way of testing and culling mechanisms of all sero-reactor ewes and their progeny. High sensitive screening test should be practiced and implemented during introduction of new flocks from abroad and before distribution of Awassi cross breed rams from ranches and multiplication center to smallholder farms and individual farmers. In addition further epidemiological study should be done in sheep producing areas of the country to know the level of infection at national and country level.

\section{ACKNOWLEDGEMENTS}

We would like to thanks for all livestock directorate members for their contribution and assistant and also Amhara Agricultural Research Institute for financial support. We would like to thanks the laboratory technicians of National Animal Health Diagnostic and Investigation Center for their huge contribution for serum analysis.

Aslantas Ö, Pinar D and Güngör B, 2002. Hatay yöresinde maedi-visna enfeksiyonunun serolojik olarak araptýrýlmasý. Vet Hek Mikrob Derg, 2: 31-34

Ayelet G, Roger F, Tibbo M and Tembley S, 2001. 
Survey of maedi-visna in the Ethiopian highland sheep. Vet J, 161(2): 208-210

Azkur AK, Gazyagci S and Aslan ME, 2011. Serological and epidemilogical investigation of bluetongue, maedi-visna and caprine arthritis-encephalitis viruses in small ruminant in Kirikkale district in Turkey. KafkasUniversitesi Veteriner Fakultesi Dergisi, 17 (5): 803-808

BoA (Bureau of Agriculture) 2000. Report on the preliminary investigation of sheep disease at sheep ranches and ram distribution sites in North Shoa. Disease Investigation Report, Bahir Dar, Ethiopia

Central Statistical Authority (CSA), 2017/18. Central Statistical Agency Agricultural Sample Survey, Federal Democratic Republic of Ethiopia, Central Statistical Authority, volume II report on livestock and livestock characteristics

Fournier D, Cambell JR and Middleton DM, 2006. Prevalence of maedi-visna infection in culled ewes in Alberta. Can vet J, 47(5): 460-466

Garedew L, Ayelet G, Yilma R, Bekele AZ and Gelaye $\mathrm{E}, 2010$. Isolation of diverse bacterial species associated with maedi-visna infection of sheep in Ethiopia. Afr J Microbiol Res, 14 (1): 14-21

Gerstner S, Adamovicz JJ, Duncan JV, Laegreid WW, Marshall KL et al., 2015. Prevalence of and risk factors associated with ovine progressive pneumonia in Wyoming sheep flocks. J Am Vet Med Assoc, 247(8): 932-937, doi: 10.2460/ javma.247.8.932

Getachew T, Haile A, Wurzinger M, Rischkowsky B, Gizaw S et al., 2016. Review of sheep crossbreeding based on exotic sires and among indigenous breeds in the tropics: An Ethiopian perspective. Afr J Agric Res, 11(11): 901-911, doi: 10.5897/AJAR2013.10626

Getnet A, Asegedech S and Hassen C, 2010. Seroepidemiological study on Maedi-Visna in selected areas of Ethiopia. Ethiop Vet J, 14 (1): $101-111$

Gizaw S, Abegaz S, Rischkowsky B, Haile A, Okeyo AM et al., 2013. Review of sheep research and development projects in Ethiopia. Nairobi, Kenya: International Livestock Research Institute (ILRI)
Hananeh W and Barhoom S, 2009. Outbreak of MaediVisna in sheep and goats in Palestine. World Appl Sci J, 7(1): 19-23

Hüttner K, Seelmann M and Feldhusen F, 2010. Prevalence and risk factors for Maedi-Visna in sheep farms in Mecklenburg-Western-Pomerania. Berl Münch Tierärztl Wochenschr , 123: 10-14, doi: 10.2376/0005-9366-123-10

Jones C and Hunt R, 1983. Veterinary Pathology, $3^{\text {rd }}$ edn., Lea and Febiger, Philadelphea, pp466-468

Kahn C, Line S and Aiello S, 2005. Merck Veterinary Manual, National Publishing Inc., Philadelphia, pp1233-1235

Lujan L, Begara I, Collie DDS and Watt NJ, 1994. Ovine lentivirus (Maedi-visna virus) protein expression in sheep alveolar macrophages. Vet pathol, 31(6): 695-703, doi: 10.1177/ 030098589403100610

Mahin L, Chadli M and Houwers DJ, 1984. A preliminary report on the occurrence of maedivisna in sheep in Moroco.Vet Quart, 6(2): 104, doi: 10.1080/01652176.1984.9693921

Murphy FA, Gubbs EP, Horzinek MC and Studdert MJ, 1999. Veterinary Virology, $3^{\text {rd }}$ edn., Academic publisher, San Diago, pp175-385

Norouzi B, Razavizadeh TA, Azizzadeh M, Mayameei A and Mashhadi VNN, 2015. Serological study of small ruminant lentiviruses in sheep population of Khorasan-e-Razavi province in Iran. Vet Res Forum, 6(3): 245-249

Nowicka D, Czopowicz M, Mickiewicz M, SzalusJordanow O, Witkowski L et al., 2014. Diagnositic performance of ID screen MVV-CAEV Indirect screening ELISA in identifying small ruminant lintivirus- infected goats. Polish J Vet Sci, 17(3): 501-506, dol: 10.2478/pjvs-2014-0072

Peterhans E, Greenland T, Badiola J, Harkiss G, Bertoni $\mathrm{G}$ et al., 2004. Routes of transmission and consequences of small ruminant lentiviruses (SRLVs) infection and eradication schemes. Vet Res, 35(3): 257-274, doi: 10.1051/ vetres:2004014

Preziuso S, Or ME, Gimmarioli M, Kyar A, Feliziani F et al., 2010. Maedi-visna virus in Turkish sheep: a preliminary serological survey using ELISA test. 
Turk J Vet Anim Sci, 34(3): 289-293, doi: 10.3906/vet-0905-35

Preziuso S, Sanna E, Sanna MP, Loddo C, Cerri D et al., 2009. Association of Maedi Visna virus with Brucella ovis infection in rams. Eur J Histochem, 47(2): 151-158, doi:10.4081/821

Radostits OM, Gay CC, Blood DC and Hinchcliff KW, 2000. Veterinary Medicine. A Textbook of Diseases of Cattle, Sheep, Pigs, Goats and Horses, $9^{\text {th }}$ edn., Harcourt publishers limited, London Philadelphia, pp701-967

Seyoum Z, Bitew M, Teferi M and Gelaye E, 2011. Evaluation of control program of Maedi- visna by foster feeding with cow colostrums and other measures. Glob Vet, 6(1): 96-96

Shuaib M, Green C, Rashid M, Duizer G and Whiting TL, 2010. Herd risk factors associated with seroprevalence of Maedi-visna in the Manitoba sheep population. Can vet J, 51(4): 385-390

Sihvonen L, Nuotio L, Rikula U, Hirvelä-Koski V and Kokkonen U, 2000. Preventing the spread of maedi-visna in sheep through a voluntary control programme in Finland. Prev Vet Med, $47(3)$ : 213-220, doi: 10.1016/s01675877(00)00162-8

Simard C and Morley RS, 1991. Seroprevalence of maedi-visna in Canadian Sheep. Can J Vet Res, 55(3): 269-273

Tefera N and Mulate B, 2016. Seroprevalence of Maedi-Visna in sheep in selected districts of Amhara region, Ethiopia. Bull Anim Health Prod Afr, 64(4): 423-430

Thrusfield M, 2007. Sampling In: Veterinary
Epidemiology, $3^{\text {rd }}$ edn., London: Black Well Science Ltd., pp179-284

Tibbo M, 2006. Productivity and health of indigenous sheep breeds and crossbreds in the central Ethiopia highlands. PhD dissertation. Department of Animal Breeding and Genetics, Faculty of Veterinary Medicine and Animal Sciences, Swedish University of Agricultural Science (SLU), Uppsala, Sweden

Tibbo M, Woldemeskel M and Gopilo A, 2001. An outbreak of respiratory disease complex in sheep in central Ethiopia. Trop Anim Health Prod, 33: 355-365, doi: 10.1023/ A:1010565905004

Tsegaw F and Ademe Z, 2012. Serological survey of maedi-visna virus infection in highland sheep at raches and smallholder farms in eastern Amhara region, Ethiopia. Bull Anim Health Prod Afr, 60(3): 287-295

Vorster JH, Dungu BB, Marias LC, York DF, William RR et al., 1996. A perspective on Maedi/Visna in South Africa. J South Afr Vet Assoc, 67: 2-3

Woldemeskel M, Tibbo M and Potgieter LND, 2002. Ovine progressive pneumonia (Maedi-Visna): an emerging respiratory disease of sheep in Ethiopia. Dtsch Tierarztl Wochenschr, 109(11): 486-488

Zegeye A, Belayineh N, Shinkute A, Lakew M and Tesfaye A, 2014. On-Station retrospective epidemiologic study of small ruminant disease in Sirinka Agricultural Research Center, Sheep and Goat Breeding, evaluation and distribution site. Acad J Anim Dis, 3(3): 39-44, doi: 10.5829/ idosi.ajad.2014.3.3.9169 